\title{
Rates of Landsliding and Cliff Retreat Along the Big Sur Coast, California-Measuring a Crucial Baseline
}

teep topography, active faults,
diverse geology, and
seasonal storms combine to
make the rugged Big Sur area
one of the most landslide-prone
stretches of the California
coast. Landslides in Big Sur
frequently damage the popular
and economically essential
Coast Highway and may impact
nearshore marine life. To assist
State and Federal agencies in
managing this coastline, U.S.
Geological Survey (USGS)
scientists are studying the
processes and effects of land-
sliding and coastal retreat in
Big Sur.

Along central California's Big Sur coast, the rugged Santa Lucia Mountains descend abruptly into the Pacific Ocean. Millions of visitors travel annually along the Coast Highway (California Highway 1) to explore the area's dramatic topography, ancient redwood forests, and unique marine habitats, bringing many millions of dollars to the local economy.

Maintaining safe access along the Coast Highway is essential for both tourism and the livelihood of local residents. However, Big Sur's extreme topography makes the area highly susceptible to landslides. Landslides frequently block the highway, and because disposal of landslide debris into the adjacent Monterey Bay National Marine Sanctuary (MBNMS) could damage critical marine habitats, maintenance of the highway is expensive and controversial.

U.S. Geological Survey (USGS) scientists are studying

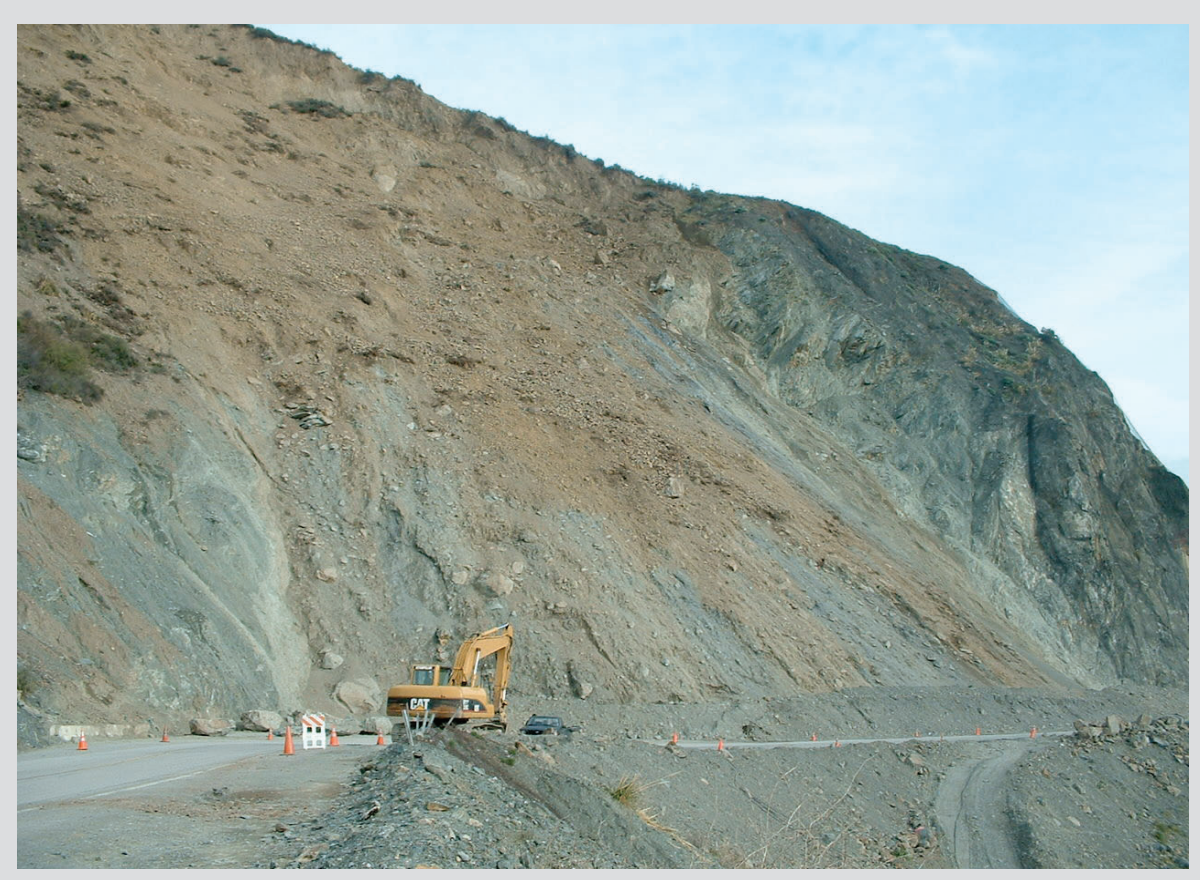

California Department of Transportation (Caltrans) crews work to reopen Highway 1 at Pitkins Curve during winter 2004. When this photograph was taken, one lane of the highway was still closed (note boulders at lower left behind the traffic barricade). This site is currently the most active landslide on the Big Sur coast. (USGS photograph by Cheryl J. Hapke.)

the rates and processes of erosion, transportation, and deposition of slope material to estimate the annual volume of sediment (sediment yield) that enters the MBNMS from landslides. This research aims to assist the efforts of Federal and State agencies in coastal planning.

\section{Why Is the Big Sur Coast Prone to Landsliding?}

In the Big Sur area, earthquakes can result in uplift of the Santa Lucia Mountains. Recurrent uplift, in combination with relentless erosion by ocean waves, creates extreme topography, making the area highly susceptible to landslides. Rocks that have been weakened through faulting and fracturing also help provide ideal condi- tions for large landslides. During the winter months, Big Sur receives both heavy rainfall (as much as 80 inches per year) and high wave energy. In summer and fall, occasional wildfires remove vegetation, making the area's slopes more vulnerable to erosion. All these factors produce chronic landslides, such as those that block, undermine, or damage the Coast Highway. For example, a 1983 landslide near Julia Pfeiffer Burns State Park resulted in closure of the highway for more than a year. Subsequent repairs cost more than $\$ 7$ million and generated nearly 3 million cubic yards of debris.

In all, more than 1,500 landslides have been mapped along the Big Sur coast. The most common type of landslide in this area is a rockslide, which is a slow-moving or 
EROSION RATES AND ROCK TYPES ALONG THE BIG SUR COAST

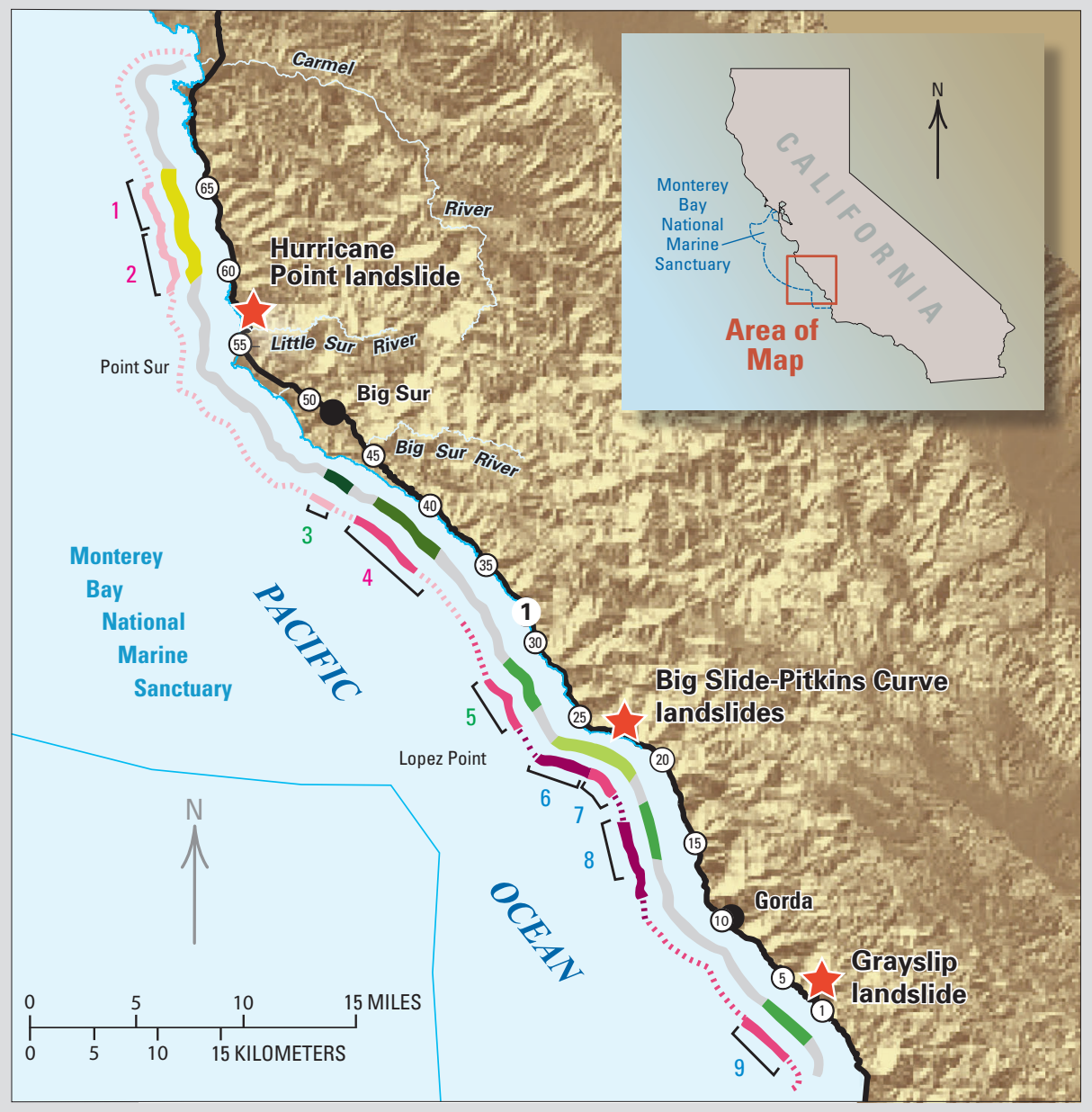

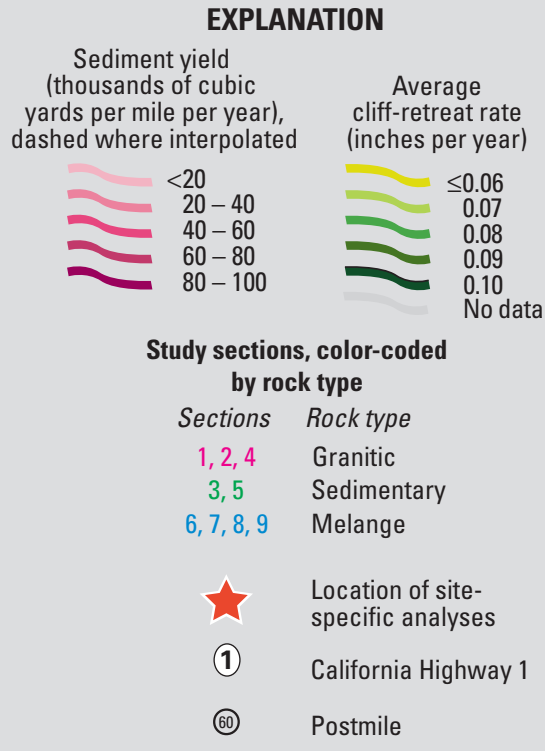

California's Big Sur coast is characterized by several rock types, which greatly influence rates of coastal erosion. Important rock types include granitic rocks, sedimentary rocks, and melange la jumbled mixture of tectonically broken and crushed rocks). This map shows the results of U.S. Geological Survey studies of rates of sediment-yield (outer color band) and cliff-retreat (inner color band) at nine sites along the Big Sur coast. The highest rates were found along the southern part of the coast, where the weakest rocks occur. In addition, three large landslides (red stars) were studied in much greater detail. "creeping" landslide in weathered, fractured, or otherwise-weakened rock. Movement on deep-seated rockslides typically is only fractions of an inch per year; however, an increase in rainfall or slope instability can accelerate movement to several yards a minute or faster.

\section{Long-Term Rates of Landslide Movement}

USGS studies of the rates of landslide movement along the Big Sur coast are providing data essential to effective management of the Coast Highway. For example, the longterm average annual sediment yield from movement on large landslides along the coast is approximately 25,000 cubic yards per mile, a volume equivalent to more than 2,700 dumptruck loads. In addition to these high rates of material loss, cliff edges are retreating landward at an average rate of about 7 inches per year.
Both sediment-yield and cliffretreat rates vary significantly along the Big Sur coast, partly because of its complex geology. Lower rates generally occur within granitic rocks, which are less faulted and fractured, whereas higher rates occur where weaker, sheared and fractured sedimentary and metamorphic rocks of the "Franciscan Complex" are dominant. In addition to rock strength and type, other factors also influence coastal-cliff erosion and movement on deep-seated landslides, including the previous history of slope disturbance (natural or human), the distribution and density of faults and fractures, variation in rainfall, and protection (or lack thereof) at the slope base by beaches or debris fans.

Although the average rates of sediment yield and cliff retreat are useful for long-term planning in coastal management, landslides are generally localized and highly episodic. In a single year, one large slope failure can account for most of the sediment yield or cliff retreat within a given area over a decade or longer. Owing to this episodic activity, average rates provide little information as to how much material may be eroded or deposited during any given year or even over the course of a decade.

\section{Short-Term Rates of Landslide Movement}

To better understand landslide rates and processes, as well as sediment yield, along the Big Sur coast, USGS scientists documented the short-term (decades long) rate of movement and the evolution of three large chronic landslides (Hurricane Point, Big Slide-Pitkins Curve, and Grayslip). The focus of this study was to quantify the variation in the rate of sediment input to MBNMS waters directly from coastal landslides, 


\section{SITE-SPECIFIC ANALYSES OF CHRONIC LANDSLIDES}
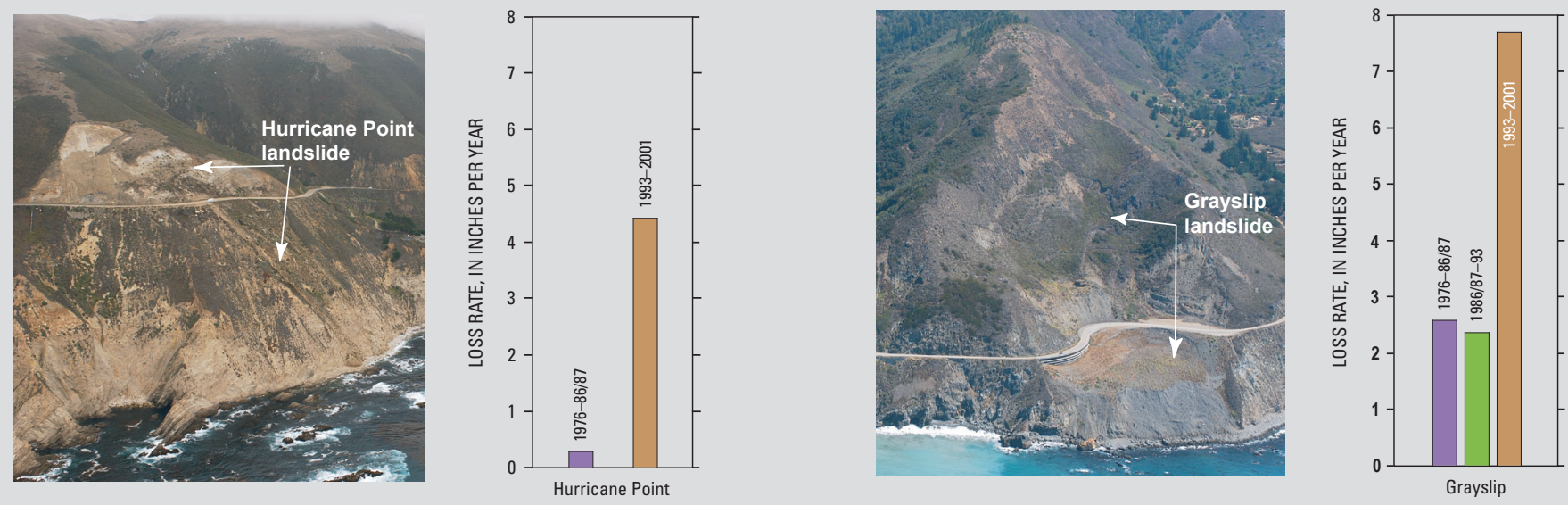

To better understand landslide processes along the Big Sur coast, U.S. Geological Survey scientists studied three chronic landslide areas-Hurricane Point, Big Slide-Pitkins Curve, and Grayslip. Using computer analysis of aerial photographs taken over three short time intervals (1976-86/87,

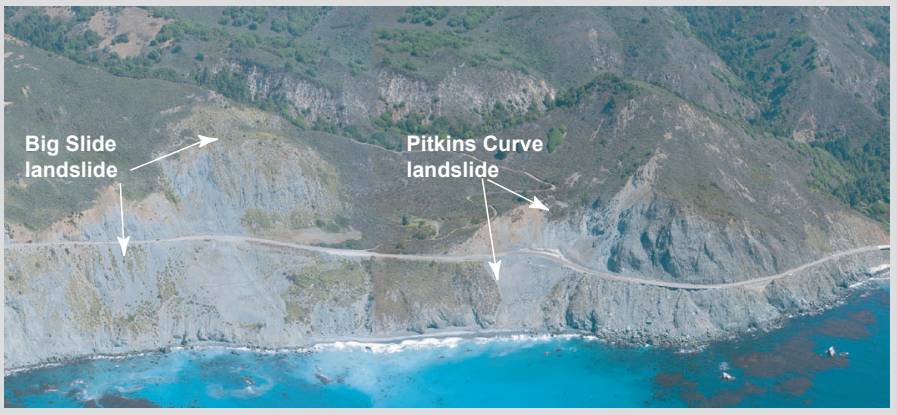
1986/87-93, and 1993-2001), the scientists calculated vertical changes in topography, or "material-loss rate," over time (for example, see Calculating Material-Loss Rates at right). The results indicate that net loss rates vary substantially along the coast. The bar graphs show that loss rates are lowest at Hurricane Point, which is within less fractured and faulted rocks. The graphs also show that in the interval containing the 1997-98 El Niño, loss rates at all three sites increased by an average of 5 inches per year from the preceding interval. (Photographs copyright by Kenneth Adelman, California Coastal Records Project, http://www.californiacoastline.org/.)

and to characterize the processes responsible for sediment delivery.

For this study, three-dimensional topographic models were created from aerial photographs over three time intervals (1976-86/87, 1986/8793, and 1993-2001) spanning a total of 25 years. Computer analysis of these models using a geographic information system (GIS) showed that net short-term rates of material loss vary substantially along the coast, apparently in relation to both local rock types and climatic triggers. For example, the loss rates at Hurricane Point, which is within

\section{Calculating Material-Loss Rates}
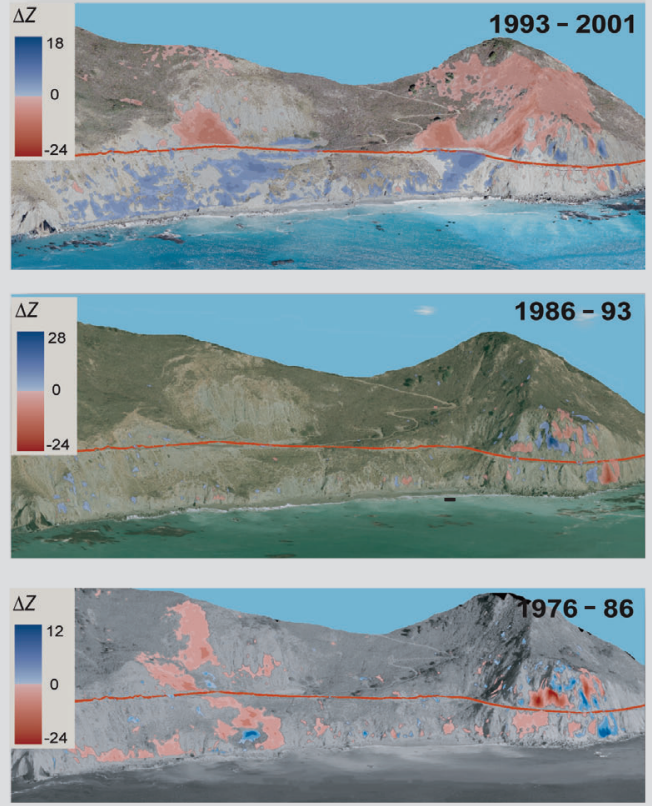

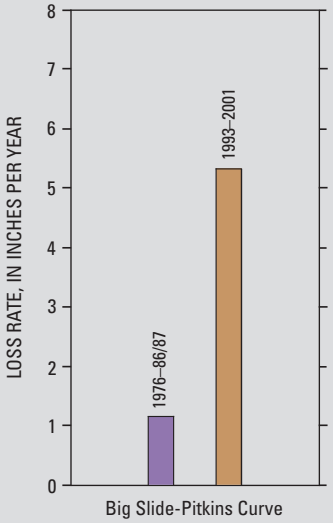

This series of images of the Big Slide-Pitkins Curve landslide area shows where material has been eroded (red) or deposited (blue) owing to landslide movement during three time intervals from 1976 to 2001. Material-loss rates are derived by dividing the change in elevation in yards ( $\triangle \mathrm{Z})$ by the number of years in the interval. less fractured and faulted rocks, are the lowest of those at the three sites, whereas the loss rates within weak rocks at the central and southern sites (Big Slides-Pitkins Curve and Grayslip landslides, respectively) are the highest.
Historically, landslide activity greatly increases during large El Niño years (for example, 1940-41, 1982-83, and 1997-98). The time intervals within this analysis that contain two of the largest recorded El Niño events also showed greatly 


\section{BIG SUR LANDSLIDES MAY THREATEN NEARSHORE MARINE LIFE}

Rocky substrates in the
nearshore waters of
Monterey Bay National
Marine Sanctuary
provide essential habi-
tats for many marine
species. Along the Big
Sur coast, both natural
landslides and human
activities can intro-
duce large volumes of
sediment into sanctu-
ary waters, potentially
impacting these habi-
tats. This may affect
not only bottom-dwell-
ing species-including
anemones, starfish,
and sea urchins-but
also the animals that
feed on them, such as
the southern sea otter,
a protected marine
mammal.

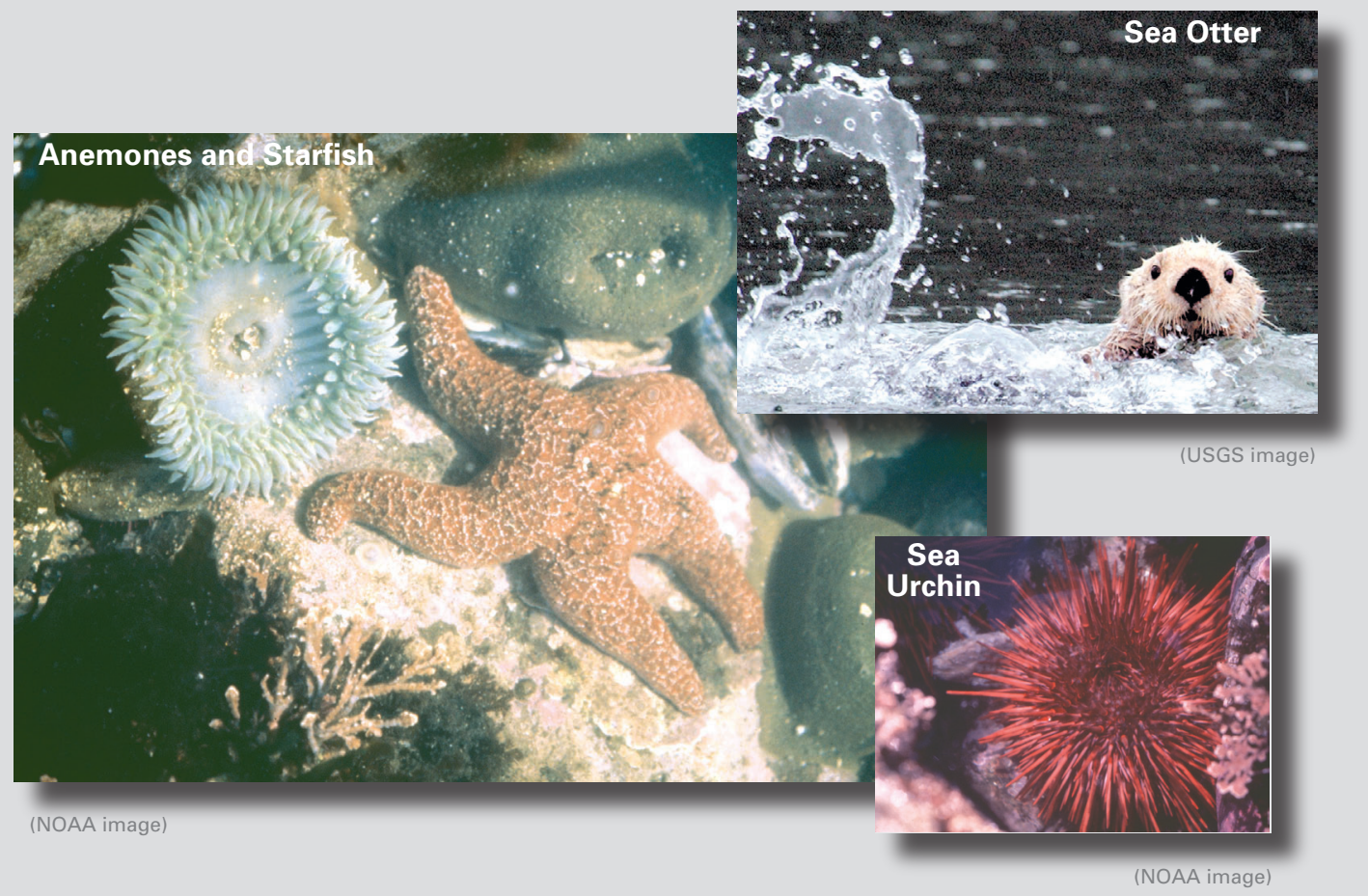

increased net material-loss rates, especially the interval containing the 1997-98 El Niño, when loss rates increased by 5 inches per year from the earlier non-El Niño interval (1986/87-93). At all three sites, movement on large creeping landslides mobilized material and deposited it on the lower slope or slope base. Subsequent smaller failures in the loose material, as well as wave erosion at the slope base, resulted in a net loss of material to the nearshore environment, ranging from about 4 to 7 inches per year.

\section{Could Landslides Be Affecting Nearshore Marine Habitats?}

Landslides and coastal-cliff erosion contribute material to adjacent ocean waters. Deposition of large amounts of sediment and increased suspended-sediment concentrations may pose a threat to some marine life. However, restricting sediment input could also harm the nearshore environment because debris from coastal erosion and landslide activity also supplies nutrients and provides a natural buffer to protect cliffs from erosion by wave attack.

By studying the volume of sediment that has historically entered MBNMS waters from landslide movement and coastal-cliff retreat, USGS scientists are providing a sediment-yield baseline against which the impact of human activities along the Big Sur coast can be evaluated by coastal planners. Before the MBNMS was established in 1992 , both natural landslide debris and excess material generated from efforts to stabilize slopes were sometimes deposited on the seaward side of the highway to clear it for traffic. This material could then be carried downslope and into the MBNMS, disrupting nearshore habitats.

Coastal landslides continue to be problematic along the Big Sur coast and in other similar high-relief sections of the Pacific coast. USGS research will help in the development of new coastalmanagement practices designed to minimize environmental impacts, while preserving the beauty and protecting the natural resources along this evolving coastline. Such research is only one part of the USGS' efforts to protect people's lives and property from geologic and environmental hazards in the coastal zones of the United States.

Cheryl J. Hapke and Krystal R. Green

Edited by

George A. Havach, James W. Hendley II, and Peter H. Stauffer Graphic design by Susan Mayfield and Stephen L. Scott

\section{COOPERATING ORGANIZATIONS}

California Department of Transportation Monterey Bay National Marine Sanctuary University of California, Santa Cruz

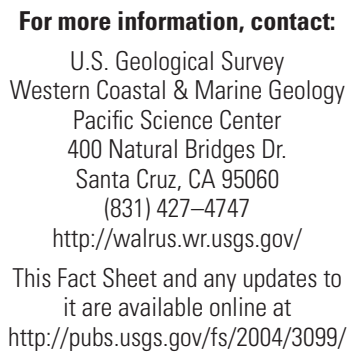

